\title{
The status and habitat of Karamoja Apalis Apalis karamojae in the Wembere Steppe, Sukumaland, Tanzania
}

PHILIP SHAW and ELIAS MUNGAYA

\section{Summary}

Karamoja Apalis Apalis karamojae is a globally Vulnerable warbler, restricted to north-east Uganda, north-central Tanzania and southern Kenya. Here, we describe its status and habitat in the Wembere Steppe, Sukumaland, Tanzania, an unprotected area of seasonally inundated grassland bordered partly by Acacia scrub. Although its habitat in the steppe was thought likely to span c. $175 \mathrm{~km}$ north-south during the $1960 \mathrm{~s}$ to 1970s, we found the apalis to be patchily distributed over a distance of only $102 \mathrm{~km}$ north-south. Distance sampling yielded a density estimate of $c .7-16$ birds $\mathrm{km}^{-2}$; equivalent to $c .3-7$ pairs $\mathrm{km}^{-2}$, after juveniles ( $18 \%$ of the population) were excluded, and assuming that all adults were paired. The species occupied a very narrow foraging niche, feeding almost exclusively in Whistling Thorn Acacia drepanolobium, which accounted for $66 \%$ of woody stems in the study area, but for $95 \%$ of stems in the immediate vicinity of apalis sightings. Half of all individuals were encountered in the tallest, densest stands of $A$. drepanolobium, which covered less than $6 \%$ of the study area. Signs of scrub clearance, pruning and browsing were widespread in the steppe, and may have intensified during 1967-2002, when the human population in surrounding districts increased at a mean rate of c. $2-4 \%$ per year. Further research is required to determine whether our findings are representative of the species in other seasons and at other sites.

\section{Introduction}

The Karamoja Apalis Apalis karamojae is a globally Vulnerable, restricted-range warbler, discovered in Karamoja District, north-east Uganda in 1919 (Collar and Stuart 1985, Stattersfield et al.1998, BirdLife International 2000). Known from only four sites in Uganda (Stattersfield et al. 1998), its status there remains unclear, due in part to the prolonged civil conflict affecting much of the northern part of the country (Rainey 1996). In 1961 the species was discovered in Tanzania, on the margins of the Wembere Steppe, an area of seasonally inundated grassland straddling the border between the Tabora and Singida Regions (Stuart and Collar 1985). The Wembere Steppe lies on the edge of an area known as Sukumaland, which extends north to Lake Victoria. Since the I990s the Karamoja Apalis has also been recorded in Serengeti National Park and adjacent protected areas, over $100 \mathrm{~km}$ north of the steppe (Baker and Baker 2002), and on the northern edge of the Masai Mara National Reserve, Kenya (P. S. pers. obs., 2004).

In both parts of its disjunct range Karamoja Apalis is found in semi-arid scrub. During the 196os this was thought likely to border the Wembere Steppe throughout its length, forming a band of suitable habitat some $175 \mathrm{~km}$ long (Collar and Stuart 
1985). The apalis is particularly associated with Whistling Thorn Acacia drepanolobium and White Thorn A. seyal (Urban et al. 1997), both of which occur in black cotton soil, characteristic of seasonally inundated land. Such conditions also support productive grasslands, favoured by Wasukuma pastoralists, whose population and livestock have increased substantially in Sukumaland over the past century (Meertens et al. 1995). During 1967-2002, the human population in the three Regions bordering the steppe rose by $138-242 \%$, equivalent to an average annual increase of 3.9-6.9\% (from National Bureau of Statistics 1982, 1991, 2003). The associated demand for farmland and pasture, coupled with the effects of a tsetse control programme during the 1920s to 1930s, has resulted in the formation of a largely treeless "cultivation steppe" (Meertens et al. 1995), which may now separate the Wembere Steppe from the Serengeti ecosystem.

Based on an examination of museum skins, Stuart and Collar (1985) recognized the Tanzanian population of Karamoja Apalis as a distinct subspecies, A. k. stronachi. Aside from their study, and despite its threatened status, there has been no substantive work on the apalis, nor any specific action taken to safeguard it. Consequently, little is known of its habitat, distribution or abundance in the steppe, one of the largest, most threatened unprotected Important Bird Areas (IBAs) in Tanzania (N. E. Baker in litt., 2002). Most aspects of the warbler's ecology, including its food, nest and eggs, remain undescribed (Urban et al. 1997). A first description of its voice, which is atypical of the genus Apalis, is given in Shaw et al. (2005).

On the basis of a survey carried out in July 2003, we show that Karamoja Apalis were less widely distributed in the Wembere Steppe than had been assumed, occurred at a relatively low density, and occupied a very narrow foraging niche. Signs of pressure on its habitat, in the form of scrub clearance and pruning, were widespread.

\section{Methods}

The study area

The Wembere River rises at c. $6^{\circ} \mathrm{S}$ in Tabora Region, Tanzania, from where it flows for about $230 \mathrm{~km}$ north into Lake Kitangire. Lying at an altitude of c. 1,060 m, and with a maximum width of $c .30 \mathrm{~km}$, the steppe through which it flows normally floods during December to April. Dominant soil types include black cotton soil (Meertens et al. 1995), a type associated with seasonal flooding, which few woody species are able to tolerate. The central grasslands of the steppe are grazed heavily by cattle and sheep, belonging mainly to Wasukuma and Wataturu pastoralists, who live in settlements along its edge. The area is considered likely once to have supported considerable numbers of wild ungulates and other large mammals, whose decline has been attributed to habitat degradation and poaching (Baker and Baker 2002).

For most of its length the steppe is bordered by areas cleared for pasture or cultivation, and by occasional stands of semi-arid scrub. During the 1960s this fringe vegetation reached $c .3 \mathrm{~km}$ wide in places and was dominated by Acacia seyal and Balanites aegyptiaca, giving way to stands of A. mellifera, Commiphora sp., $A$. stuhlmannii, A. kirkii and A. drepanolobium (B. W. H. Stronach in litt., 1983). The latter is a small tree, bearing pairs of long $(c .7 \mathrm{~cm})$ stipular spines, some of which have at their base a round, hollow 'pseudo-gall', up to $8 \mathrm{~cm}$ in diameter (Coe and Beentje 1991). 


\section{Assessing distribution}

During July 2003 we searched for Karamoja Apalis in Acacia scrub fringing the steppe, and at known sites as far west as Nzega (Figure 1). The western edge of the steppe was searched to a point $102 \mathrm{~km}$ south of Igunga Town, where woodland on either side of the steppe merged in the centre. Parts of the eastern edge were also searched, as was a track linking Igunga with Meatu, $97 \mathrm{~km}$ to the north. All patches of Acacia scrub or woodland encountered were searched briefly, using taped song to elicit a response from apalis groups. The main Acacia species in each patch were noted, and the location of the patch recorded using a Garmin 12 GPS.

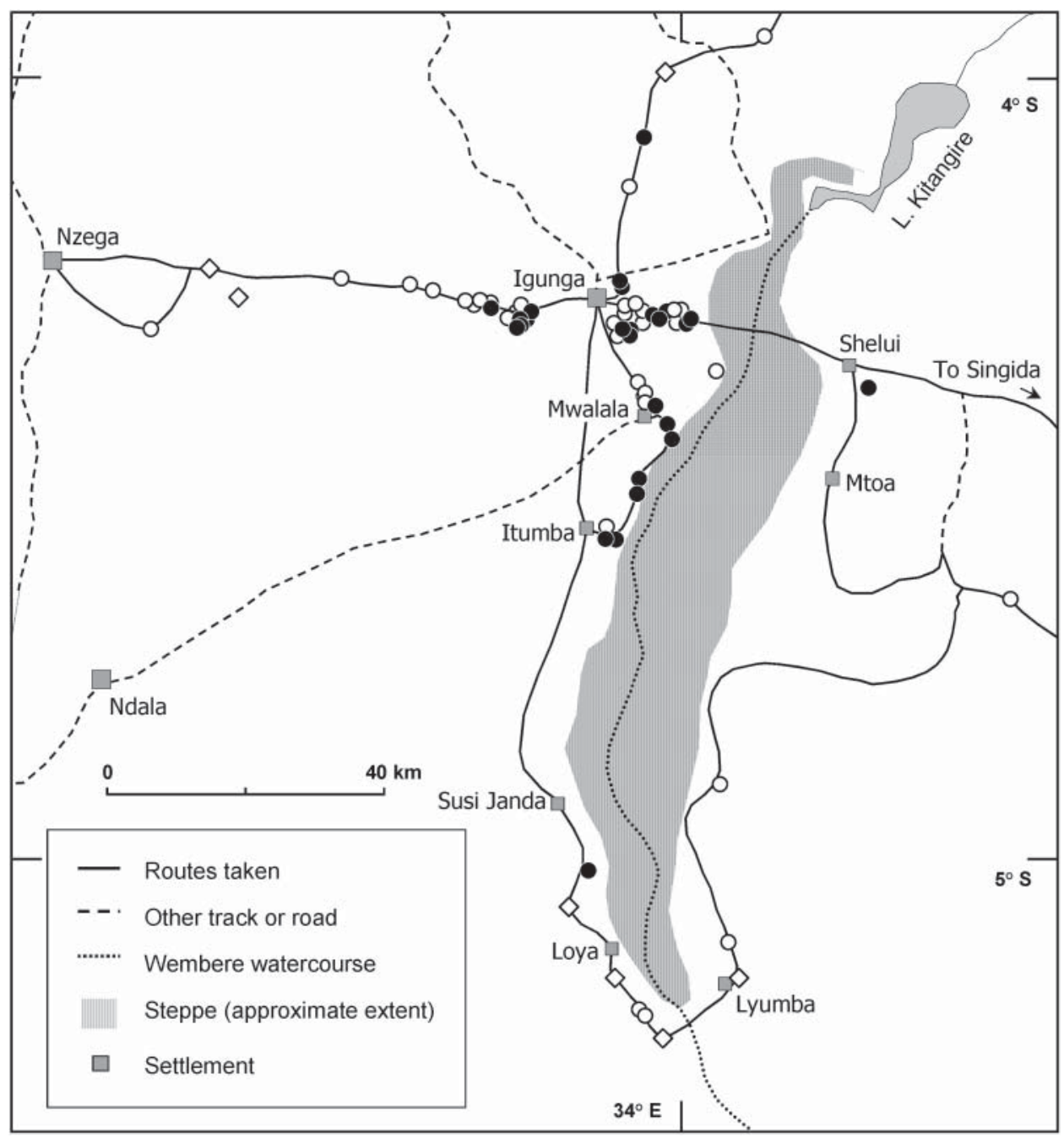

Figure 1. Locations at which Karamoja Apalis were recorded in the vicinity of the Wembere Steppe. - stand of Acacia drepanolobium with Karamoja Apalis present; $\bigcirc$, unoccupied stand of Acacia drepanolobium; $\diamond$, unoccupied stand dominated by other Acacia species. All Acacia stands encountered along the routes taken (unbroken lines) were surveyed briefly. 


\section{Transect surveys}

Abundance, habitat requirements, feeding niche and biometrics were measured at four sites at which there was moderate or extensive $A$. drepanolobium cover: Igunga East $\left(33^{\circ} 54^{\prime} \mathrm{E}, 4^{\circ} 18^{\prime} \mathrm{S}\right)$, Igunga West $\left(33^{\circ} 46^{\prime} \mathrm{E}, 4^{\circ} 18^{\prime} \mathrm{S}\right)$, Itumba $\left(33^{\circ} 53^{\prime} \mathrm{E}, 4^{\circ} 34^{\prime} \mathrm{S}\right)$ and Mwalala $\left(33^{\circ} 56^{\prime} \mathrm{E}, 4^{\circ} 24^{\prime} \mathrm{S}\right)$. Abundance and habitat data were collected from 36 $1 \mathrm{~km}$ transects. Each followed a triangular route (with sides of 330,330 and $340 \mathrm{~m}$ ), minimizing the travel time between the end of one transect and the start of the next. Care was taken to avoid double counting of bird contacts (e.g. near the apices). Transect lengths were measured using a pedometer and checked by GPS.

At Igunga East, transects were located on either side of the main $\mathrm{T}_{3}$ road, which bisected the study area. The start of each transect was located by walking or driving a fixed distance from the previous transect, and to a point $500 \mathrm{~m}$ in a perpendicular line from the road. Where a vehicle was used, the start of the transect was located by first pacing $50 \mathrm{~m}$ due east of the vehicle, to minimize any disturbance the vehicle may have caused. The transect was then begun after a short delay, during which habitat features at that point were assessed. Although the areas surveyed did not constitute a random sample of the site, they were considered to be representative of the mosaic of habitats present. The area of apparently suitable habitat at Igunga West was smaller and was surveyed more intensively, the majority of transects being located on a grid pattern.

\section{Abundance}

The population density of Karamoja Apalis and of likely competitor species was estimated by measuring the perpendicular distance between the transect line and each bird when first encountered (Buckland et al. 1993). The distance between the observer and the bird was measured using a Leica LRF 800 Rangefinder, by pacing or, for more distant detections, by GPS. Paced distances were compared regularly with Rangefinder readings, to check for drift in the former. A compass bearing was taken for each bird encountered, and the difference between the transect bearing and that of the bird was used to calculate its perpendicular distance from the line. Densities were estimated using Distance v 4.0, release 1. All detections were grouped (in Distance) into intervals coinciding with one or more distance bands, each band encompassing several detections. Where excessive heaping of detection distances occurred, wider intervals were selected to offset this. Four model types were fitted (half-normal, hazard-rate, uniform and negative-exponential), each with cosine, simple polynomial and hermite polynomial adjustments. Selection of the most appropriate detection function was based on minimum Akaike Information Criterion. Goodness of fit was tested by chi-square test.

\section{Habitat associations}

Habitat associations were assessed by comparing features recorded at fixed intervals along each transect ('survey points'), with those recorded in the immediate vicinity of each Karamoja Apalis individual or pair when first encountered. Parameters recorded were: study area, date, time, cloud cover, wind speed and temperature. Habitat features considered likely to influence the species' distribution or abundance 
were recorded systematically within four adjoining $50 \times 50 \mathrm{~m}$ quadrats, centred on the apices of each (triangular) transect. These were: percentage canopy cover of trees $(>1.5 \mathrm{~m}$ high) and bushes $(0.5-1.5 \mathrm{~m})$; mean grass height $(5 \mathrm{~cm}, 5-10 \mathrm{~cm},>10 \mathrm{~cm})$; land-use (pasture or cultivated); intensity of grazing and browsing (score of $1-5$ ); and signs of pruning and burning (presence/absence).

Tree and bush height, density and species composition were assessed by measuring 1o woody stems (of at least $0.5 \mathrm{~m}$ high) nearest to each apex. At Igunga East, Itumba and Mwalala, the same measurements were also made at a point exactly mid-way between each apex. Where possible, each stem was identified to species, and its height recorded in $0.5 \mathrm{~m}$ bands, up to a height of $2 \mathrm{~m}$, or in $1 \mathrm{~m}$ bands above this height. Stem density was estimated using the formula: $\Pi\left(\mathrm{dmax}^{2}\right)$, where dmax is the distance (in $\mathrm{m}$ ) between the first and tenth stem measured. Ten stems were measured nearest to and including the stem on which each Karamoja Apalis individual or pair was first encountered. Stem species, height and density were recorded at 174 survey points ( $n=1,740$ stems) and at 39 locations where Karamoja Apalis were first encountered $(n=389$ stems).

Using SYSTAT 7.0 (Steinberg and Colla 1997), a forward, stepwise logistic regression model was fitted, to investigate the relationship between each habitat variable and the species' presence or absence. Variables were initially retained in the model if the probability associated with their alpha value was less than o.1o. Interactions between retained variables were then added to the model, and were retained or rejected according to the same criterion.

\section{Foraging niche observations}

The species' foraging niche was assessed by recording the location and behaviour of foraging individuals when first encountered, and thereafter at intervals of at least I minute. When first located, or re-found, the individual's behaviour was noted after a 5 second delay, minimizing any bias towards recording conspicuous behaviour or feeding positions. Observations were continued until the individual was lost from sight, or for 10 observations, whichever came first. The following parameters were recorded: time; tree species; height of bird (in $0.5 \mathrm{~m}$ or $1 \mathrm{~m}$ bands); height of tree; position (outer tips, twig, branch, trunk, ground); distance from the outer edge of the foliage (outer $20 \mathrm{~cm}, 20 \mathrm{~cm}$ to $1 \mathrm{~m},>1 \mathrm{~m}$ from edge); substrate examined, or from which prey was taken (leaf, spine, pseudo-gall, seed pod); and method (search, glean, sally-glean, probe, lunge, handle prey) (after Remsen and Robinson 1990).

\section{Results}

\section{Distribution}

Specimens of Karamoja Apalis were first collected in the Wembere Steppe at Itumba in 1961, and at Ngongoro in 1962 (Stuart and Collar 1985). In the late 1970s and early 1980 it was present at Nzega, $98 \mathrm{~km}$ west of the Wembere, and occurred as far south as Ndala (R. K. Walton in litt., 1983) (Figure 1). During the 1990s, the species was also recorded in $A$. drepanolobium near Igunga (N. E. Baker pers. comm.). Sightings during the 1960s to 1990s thus collectively spanned an area $75 \mathrm{~km}$ east-west (E-W) (Itumba to Nzega) by $60 \mathrm{~km}$ north-south (N-S) (Nzega to Ndala), and were confined 
to the western side of the steppe. B. W. H. Stronach (in litt., 1983), however, noted that the Acacia/Commiphora system with which the species was associated seemed likely to extend throughout the steppe, which he estimated to be $c$. IIo miles long (or c. $175 \mathrm{~km}$; Collar and Stuart 1985). In contrast, the area surveyed in this study, which appeared to encompass the full length of the steppe, spanned $134 \mathrm{~km} \mathrm{~N}-\mathrm{S}$, by $114 \mathrm{~km}$ E-W, within which the most widely separated Karamoja Apalis sightings spanned $102 \mathrm{~km} \mathrm{~N}-\mathrm{S}$ and $53 \mathrm{~km} \mathrm{E-W}$. In addition to the four study sites, nine occupied patches of $A$. drepanolobium were located on the western side of the steppe, but only one was found on the eastern side. Figure 1 shows their location, and the routes surveyed.

Karamoja Apalis could be heard duetting at up to c. $200 \mathrm{~m}$, and most pairs (though not individuals) were highly responsive to taped songs, approaching closely from distances of 50 to $100 \mathrm{~m}$, and singing persistently. Since most Acacia patches were less than $c .3-4$ ha, it seems likely that any Karamoja Apalis pairs present were detected in the majority of cases, either by their song or through their response to the tape.

\section{Abundance}

Individuals were detected from 23 of the 36 transects surveyed, at a rate of 1.9 birds $\mathrm{km}^{-1}$ walked. The encounter rate was noticeably higher during morning transects (2.3 birds $\mathrm{km}^{-1}$ ), than in the late afternoon ( 0.9 birds $\mathrm{km}^{-1}$ ). All detection data from the four survey sites were pooled and detections more than $160 \mathrm{~m}$ from the transect were discarded. The four models applied yielded similar density estimates, of between c. 10 and 14 birds $\mathrm{km}^{-2}$ (Table 1 ). A half-normal model provided the best fit (Figure 2), yielding an estimate of 10.4 birds $\mathrm{km}^{-2}$ (CL: 6.8-16.0 birds $\mathrm{km}^{-2}$ ). A second series of models, fitted to 27 transects surveyed during mornings only, yielding an estimate of 11.4 birds $\mathrm{km}^{-2}$ (CL: 7.2-17.8 birds $\mathrm{km}^{-2}$ ).

Of 89 Karamoja Apalis seen clearly, 16 (18\%) were juveniles, indicating that the adult density was correspondingly lower than the estimates given above; equivalent to c. 5.8-13.1 adults $\mathrm{km}^{-2}$. These figures suggest a breeding density of $c .3^{-7}$ pairs $\mathrm{km}^{-2}$, assuming that all adults occurred in pairs. For comparison, an empirical estimate of territory density was derived from nearest-neighbour distances. These were measured

Table 1. Density estimates of Karamoja Apalis derived from Distance sampling.

\begin{tabular}{llllll}
\hline Dataset & Detection function & Adjustments & $\begin{array}{l}\text { AIC } \\
\text { value }\end{array}$ & $\begin{array}{l}\text { Density } \\
\text { estimate } \\
\left.\text { (birds km }{ }^{-2}\right)\end{array}$ & $\begin{array}{l}\text { Confidence } \\
\text { limits }\end{array}$ \\
\hline All transects & Half-normal & None & 204.94 & 10.4 & $6.8-16.0$ \\
& Hazard-rate & None & 207.13 & 10.9 & $6.5-18.6$ \\
& Uniform & Cosine & 205.04 & 10.3 & $6.9-15.4$ \\
& Negative-exponential & None & 205.04 & 13.8 & $8.5-22.6$ \\
Morning transects & Half-normal & None & 181.08 & 11.4 & $7.2-17.8$ \\
& Hazard-rate & None & 183.31 & 11.2 & $6.6-18.9$ \\
& Uniform & Cosine & 181.21 & 11.5 & $7.5-17.6$ \\
& Negative-exponential & None & 182.01 & 14.3 & $8.5-24.0$ \\
\hline
\end{tabular}

Detections were grouped into five distance intervals: at 20,50, 80, 120 and $160 \mathrm{~m}$ from the transect. Detections made beyond $160 \mathrm{~m}$ were discarded. Four detection functions were applied to data derived from all transects $(n=36)$, and from morning transects $(n=27)$. 


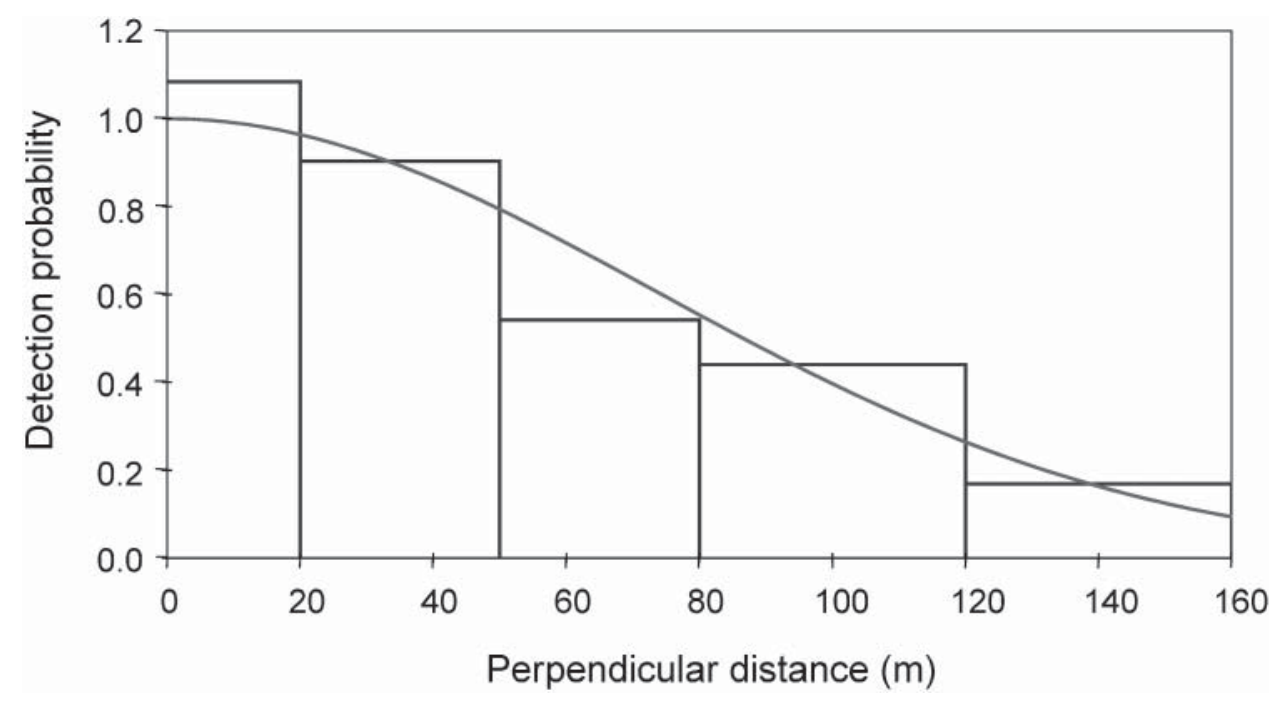

Figure 2. A detection function plot for Karamoja Apalis, right-truncated at $160 \mathrm{~m}$. To reduce the effects of 'heaping' of distance estimates, detections have been grouped into five distance intervals from the transect; at 20,50, 80, 120 and $160 \mathrm{~m}$ ( $x$-axis). A half-normal detection function has been fitted, with no adjustment terms.

mainly in Acacia-dominated areas, where adjacent pairs where more easily detected. The mean nearest-neighbour distance among 16 sets of adjacent pairs, half of which included at least one colour-ringed bird, was $0.38 \mathrm{~km}(\mathrm{CL}: 0.31-0.46)$. This suggests a density of c. 8 pairs $\mathrm{km}^{-2}$ (CL: 5.5-12.0 pairs $\mathrm{km}^{-2}$ ) in Acacia-dominated habitat; slightly higher than estimates obtained from Distance sampling within a mosaic of habitats.

The population density of Karamoja Apalis (c. 7-16 birds $\mathrm{km}^{-2}$ ) was significantly lower than that of at least one other warbler species: Rattling Cisticola Cisticola chiniana (CL: $24-60$ birds $\mathrm{km}^{-2}$ ). No other species was detected sufficiently frequently to generate comparable estimates using Distance sampling. Population density estimates for other warbler species were therefore determined from the number of birds encountered $\pm 20 \mathrm{~m}$ of the transect line, within which distance the majority of individuals present were likely to have been detected. By this method, the density estimate for Karamoja Apalis (11.3 birds $\mathrm{km}^{-2}$ ) was similar to that obtained using Distance sampling, and was lower than that for Rattling Cisticola (28.9 birds $\mathrm{km}^{-2}$ ) and Grey-backed Camaroptera Camaroptera brachyura (14.1 birds km ${ }^{-2}$ ). Both of the latter are geographically widespread, ubiquitous species, occupying a wider range of habitat types. Density estimates for six other warbler species were lower than that for Karamoja Apalis.

\section{Habitat associations}

Karamoja Apalis were found only in stands dominated by A. drepanolobium or, in one case, a mixed stand of $A$. drepanolobium and $A$. seyal. In a logistic regression model, the presence of Karamoja Apalis was positively correlated with the density of 
Table 2. Logistic regression analyses of features associated with the presence of Karamoja Apalis. ${ }^{a}$ Points at which it was first encountered were compared with transect survey points, from which it was absent.

\begin{tabular}{|c|c|c|c|}
\hline $\begin{array}{l}\text { Types of variable included } \\
\text { in the model }\end{array}$ & Variables selected & Deviance $^{b}$ & $P$ \\
\hline \multirow{5}{*}{$\begin{array}{l}\text { Location, weather, time of } \\
\text { day, land-use, habitat cover } \\
\text { and woody vegetation } \\
\text { Woody vegetation only }\end{array}$} & Density of $A$. drepanolobium stems & 35.683 & $<0.001$ \\
\hline & Tree canopy cover & 18.858 & $<0.001$ \\
\hline & Density of $A$. drepanolobium stems & 55.068 & $<0.001$ \\
\hline & $\begin{array}{l}\text { Combined height of } A \text {. drepanolobium } \\
\text { stems in sample }\end{array}$ & 12.678 & $<0.001$ \\
\hline & $\begin{array}{l}\text { Interaction between the } \\
\text { density and combined height } \\
\text { of } A \text {. drepanolobium stems }\end{array}$ & 5.102 & 0.024 \\
\hline
\end{tabular}

a Variables are listed in the order in which they were selected in each model. All variables listed showed a positive association with the dependent variable.

$b_{1}$ d.f. throughout.

cPercentage cover by stems at least $1.5 \mathrm{~m}$ tall.

A. drepanolobium stems and with mean tree canopy cover (Table 2). In a second model, based solely on variation in woody vegetation structure, the species' presence was positively correlated both with the density and the combined height of $A$. drepanolobium stems in the sample (Table 2). An interaction variable based on $A$. drepanolobium density and height improved the model fit, indicating that the species was significantly more often encountered where tall $A$. drepanolobium occurred at high densities than would be expected from the effects of either variable on its own.

The apalis showed a strong preference for foraging in A. drepanolobium, which accounted for $66 \%$ of stems at habitat survey points $(n=1,740$ stems $)$ but for $95 \%$ of stems in the vicinity of Karamoja Apalis sightings ( $n=389$ stems). At survey points, the median density and height of $A$. drepanolobium were 155 stems $^{-1}$ (range: $0-3,537$ stems $\mathrm{ha}^{-1}$ ) and $1.4 \mathrm{~m}$ (range: $0-3.6 \mathrm{~m}$ ), respectively. In contrast, Karamoja Apalis were recorded in stands of $A$. drepanolobium with a median density 8.2 times greater $\left(1,273\right.$ stems $\mathrm{ha}^{-1}$; range: $188-11,318$ stems $\left.\mathrm{ha}^{-1}\right)$ and with a median height 1.6 times greater $(2.3 \mathrm{~m}$; range: $1.4-3.7 \mathrm{~m} ; n=39$ encounters $)$ than that of the study area as a whole (Figure 3 ).

The combined height of all $A$. drepanolobium stems measured at each point was divided by the area encompassed by the 1o stems nearest to that point, providing an index of the volume of $A$. drepanolobium present. A cumulative frequency plot of this index shows that $75 \%$ of apalis encounters occurred in $A$. drepanolobium stands whose combined height and density was met or exceeded at only $15 \%$ of habitat survey points (Figure 4). Similarly, half of all apalis encounters occurred in $A$. drepanolobium stands with a combined height and density attained in only $6 \%$ of the study area.

\section{Foraging niche}

Foraging height, position and behaviour were recorded during 31 encounters, involving at least 43 individuals. To obtain an adequate sample of foraging 


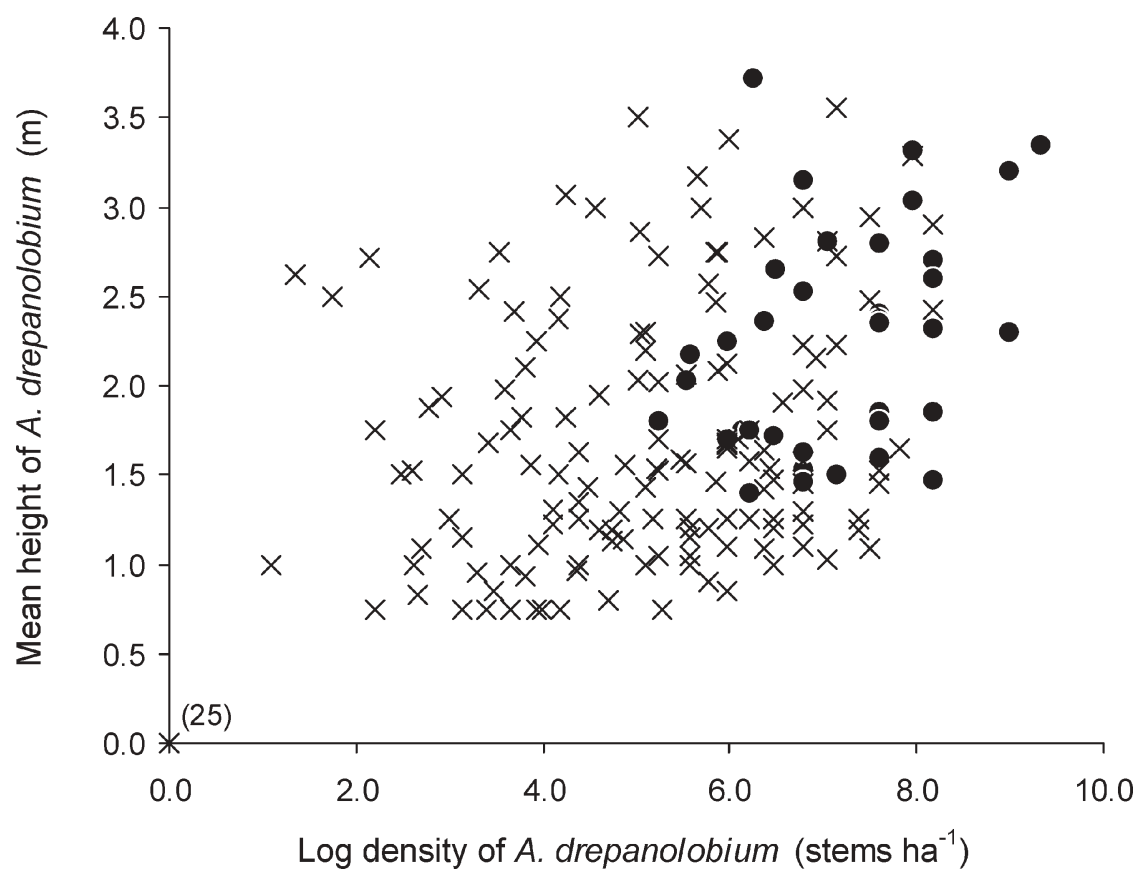

Figure 3. The density and mean height of Acacia drepanolobium at transect survey points $(X ; n=174)$ and at locations where Karamoja Apalis were first encountered $(\mathbf{O} n=39)$. Stem density is expressed as $\log \left(\right.$ stems $\left.\mathrm{ha}^{-1}+1\right)$. A. drepanolobium was absent from 25 transect survey points (indicated).

observations, up to 10 observations were made during each encounter. Results derived from this pooled dataset did not differ significantly from those based only on the first observation made during each encounter. The majority of observations $(76 \%)$ were made at the four study sites.

Of 120 observations made, $115(96 \%)$ were in A. drepanolobium, four in A. kirkii and one in $A$. nilotica. The height profile of $A$. drepanolobium trees in which individuals foraged (measured in five height classes: $0.5-1,1-2,2-3,3-4,>4 \mathrm{~m}$ ) differed significantly from that of trees sampled at transect survey points $\left(\chi^{2}=156.3\right.$; $P<$ 0.001). Trees over $2 \mathrm{~m}$ high accounted for $30 \%$ of those recorded at survey points ( $n=1,148$ trees) but for $84 \%$ of those in which apalises were observed foraging ( $n=89$ trees). The species foraged from ground level to a height of $4-5 \mathrm{~m}$, but most frequently at $2-2.5 \mathrm{~m}(24 \%$ of observations) and $1.5-2 \mathrm{~m}(22 \%)$. In addition to selecting taller trees, foraging individuals showed a preference for feeding in the upper foliage, $76 \%$ of foraging observations occurring in the upper $40 \%$ of the tree.

Feeding in the upper strata may have enabled individuals to avoid ground predators, or perhaps reflected the greater volume of foliage available at that height, since $A$. drepanolobium in the study area tended to taper from top to bottom. Alternatively, individuals foraging in the upper levels may simply have been easier to detect and to observe for longer periods, contributing disproportionately to the dataset. This seems unlikely, however, as the heights at which individuals were first detected were not significantly greater than those at which they were subsequently recorded (Mann-Whitney $U_{10,20}=73.0 ; P=0.23$ ). Similarly, there was no significant difference 


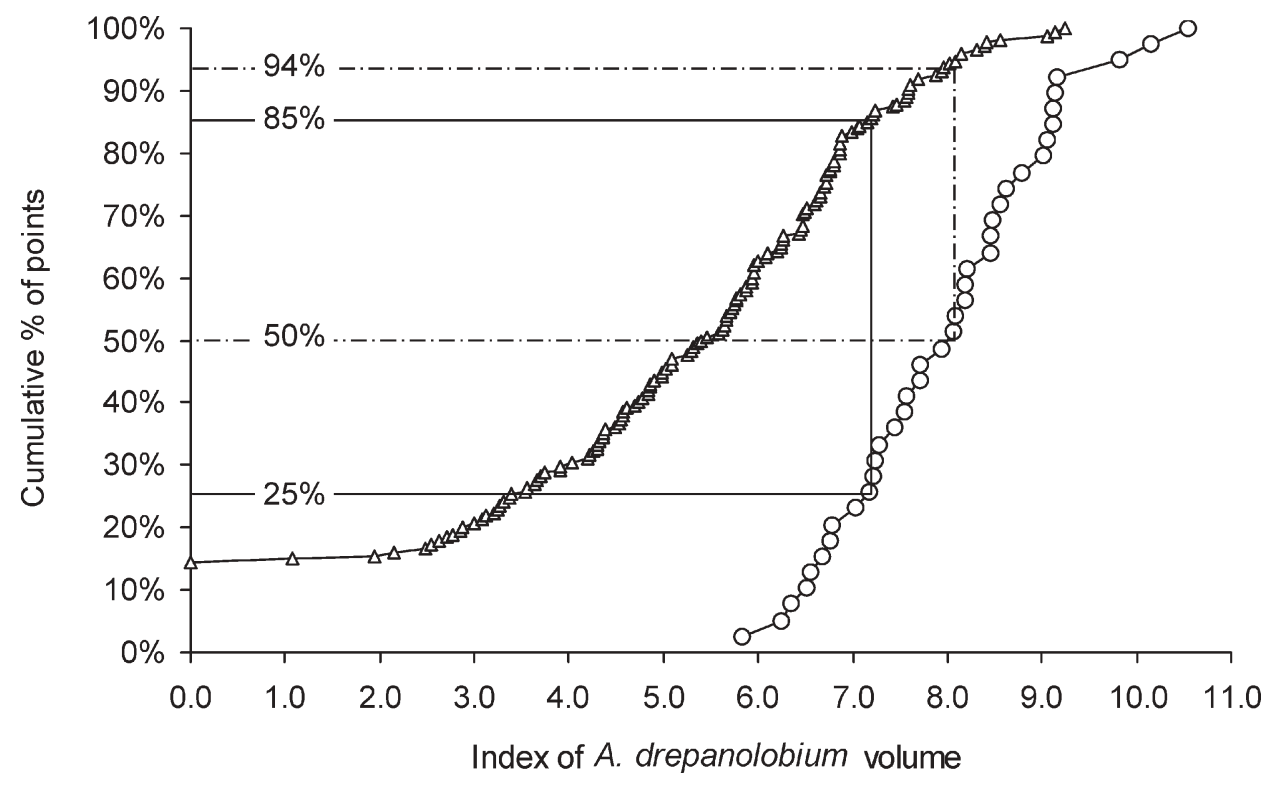

Figure 4 . The cumulative distribution of transect survey points $(\triangle ; n=174)$ and of locations at which Karamoja Apalis were first encountered $(O ; n=39)$, in relation to an index of the volume of Acacia drepanolobium present (see text). Lines intersecting the two curves show, for example, that the volume of $A$. drepanolobium recorded at $50 \%$ of apalis locations was met or exceeded only at the densest $6 \%$ of survey points.

between the foraging heights of birds lost from sight after fewer than five observations, and those observed five to 10 times (Mann-Whitney $U_{20,87}=1022.5 ; P=0.88$ ).

Foraging birds perched frequently on spines ( $42 \%$ of observations; $n=98$ ) or twigs (51\% of observations), often in the outer $20 \mathrm{~cm}$ of the foliage ( $49 \%$ of observations; $n=112)$. Foraging movements consisted of gleaning ( $42 \%$ of movements; $n=64)$, sally-gleaning $(31 \%)$, lunging $(16 \%)$ and probing $(9 \%)$. These movements were directed mainly at pseudo-galls $(31 \%$ of movements; $n=48)$, spines $(25 \%)$ or leaves $(23 \%)$, from which prey items were presumably taken. Only seven prey items were seen, comprising three larvae, a moth and other adult insects.

The species' prey and the nature of its close affinity with A. drepanolobium remain unclear, but may be linked to its unusually long bill, which markedly exceeds that of its congeners (Shaw et al. 2005), none of which is restricted to Acacia scrub (Urban et al. 1997). Mean bill length of Karamoja Apalis ( $16.3 \mathrm{~mm} ; n=17$ birds; Shaw et al. 2005) also exceeded that of 10 other insectivores with which it may compete for food (range: 8.5-15.5 mm; measurements from Urban et al. 1997, Fry et al. 2000). This difference was particularly pronounced when bill length was compared with tarsus length, as a measure of body size (Figure 5). The ratio of mean bill:tarsus length in Karamoja Apalis was 0.90:1, compared with 0.52-0.70:1 among other insectivores present.

\section{Habitat condition}

Changes in the structure and extent of Acacia drepanolobium are likely to have a direct impact on the warbler's range and abundance in the steppe. Pressures evident 


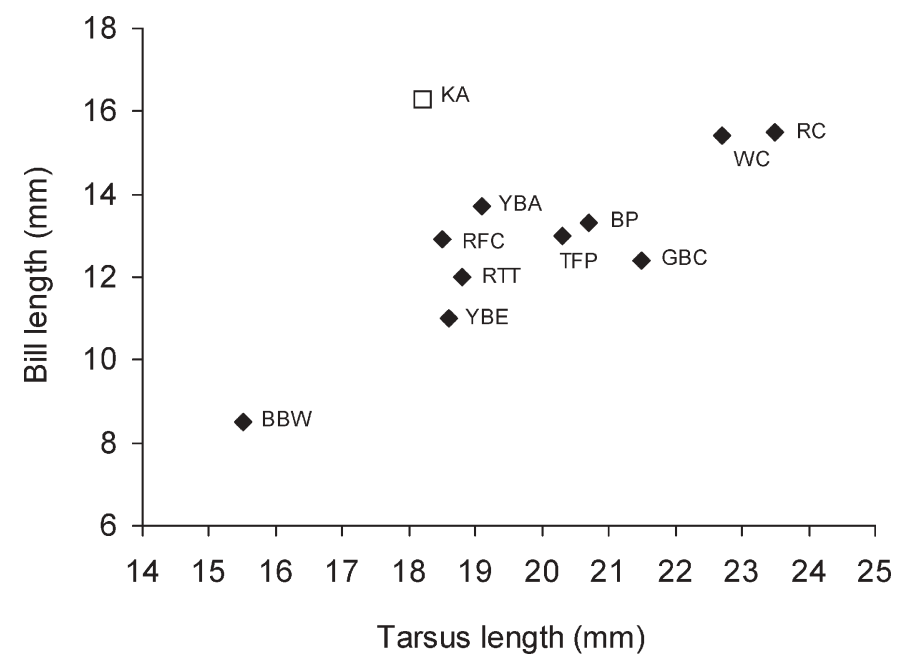

Figure 5. Bill and tarsus length of Karamoja Apalis $(\square)$ in comparison with those of potential competitor species present in the study areas $(\bullet)$. Each point represents the mean of measurements for one species, from Urban et al. (1997), Fry et al. (2000) and this study (for Karamoja Apalis). BBW, Buff-bellied Warbler Phyllolais pulchella; BP, Banded Parisoma Parisoma boehmi; GBC, Grey-backed Camaroptera Camaroptera brachyura; KA, Karamoja Apalis; RC, Rattling Cisticola Cisticola chiniana; RFC, Red-faced Crombec Sylvietta whytii; RTT, Redthroated Tit Parus fringillinus; TFP, Tawny-flanked Prinia Prinia subflava; WC, Winding Cisticola Cisticola galactotes; YBA, Yellow-breasted Apalis Apalis flavida; YBE, Yellow-bellied Eremomela Eremomela icteropygialis.

on A. drepanolobium included clearance for cultivation, cutting and pruning for firewood and hedging material, burning, browsing by goats and trampling by cattle. Scrub clearance was evident in the form of extensive open patches, in which cut or burnt $A$. drepanolobium stumps remained. At the two Igunga sites, A. drepanolobium stems were absent or sparse (fewer than 100 stems $\mathrm{ha}^{-1}$ ) at $51 \%$ of survey points, while signs of browsing were evident at $84 \%$ of points, and appeared to be moderate or severe at $70 \%$ of points $(n=114)$. Cutting or felling was evident at $81 \%$ of survey points, and was considered moderate or severe (i.e. recorded in at least three out of four quadrats) at $57 \%$ of points.

\section{Discussion}

Our findings suggest that the range of Karamoja Apalis in the Wembere Steppe was less extensive than had been assumed from observations made in the 1960s and 1970s. They also show that, at least during the study period, the apalis was more closely associated with Acacia drepanolobium than was evident from earlier accounts. Most A. drepanolobium stands showed signs of cutting or browsing, and were either shorter or less dense than those in which the apalis was typically encountered. Whether the extent or condition of $A$. drepanolobium cover in the steppe has declined in recent decades has not been ascertained, but human population and agricultural trends elsewhere in Sukumaland suggest that this is likely. 


\section{Range and abundance}

The area surveyed in this study spanned $134 \mathrm{~km} \mathrm{~N}-\mathrm{S}$. Suitable habitat was found to be very patchily distributed over a distance of $114 \mathrm{~km} \mathrm{~N}-\mathrm{S}$, within which the most distal records of Karamoja Apalis lay $102 \mathrm{~km}$ apart, N-S. Although substantially shorter than its estimated range during the 1960 and 1970 ( $175 \mathrm{~km})$, this difference is likely to reflect an improved knowledge base rather than a real decline. The most extensive occupied area of $A$. drepanolobium found lay east of Igunga Town and c. $10 \mathrm{~km}$ north-west of the Wembere Steppe IBA, as it is currently defined (Baker and Baker 2002). Karamoja Apalis were also encountered in several much smaller stands between Igunga and Itumba (Figure 1 ), and in one impoverished stand $46 \mathrm{~km}$ south of Itumba. It is possible that patches of $A$. drepanolobium occurred in the intervening area but were overlooked, in which case the apalis's distribution may be more continuous than is suggested in Figure 1.

Duetting pairs were audible at $200 \mathrm{~m}$ or more, giving an impression that the apalis was more abundant than other, less vocal warbler species. Encounter rates close to the transect line partly support this assumption, suggesting that Karamoja Apalis was the third most abundant of nine warbler species. Estimates based on Distance sampling indicate densities of c. $7^{-16}$ birds $\mathrm{km}^{-2}$; or $c .3^{-7}$ pairs $\mathrm{km}^{-2}$ once juveniles are accounted for. Note, however, that the pair density estimate does not take account of uncertainty associated with the percentage of juveniles present, and is therefore likely to be conservative. Although nearest-neighbour distances yielded a slightly higher estimate (c. 8 pairs $\left.\mathrm{km}^{-2}\right)$, this figure was considered unlikely to be representative of the mosaic of habitats typical of the study areas. In either case, the species' population density was at least an order of magnitude lower than that of most other apalis species, which occur in forest or forest-edge habitats (e.g. Dowsett-Lemaire 1989, Shaw and Shewry 2001), but was broadly similar to that of Yellow-breasted Apalis Apalis flavida in Acacia savanna in Swaziland (3-41 birds km²; Monadjem 2002).

\section{Habitat and feeding niche}

In the 1960s and 1970s, Karamoja Apalis in the Wembere Steppe were recorded in mixed stands of A. kirkii, A. mellifera and Commiphora sp. (B. W. H. Stronach in litt., 1983), although J. F. Reynolds (in litt., 1983) noted a preference for $A$. drepanolobium. Our results indicate that, at least in July, Karamoja Apalis in the Wembere Steppe foraged almost exclusively in particularly tall, dense $A$. drepanolobium. Within these stands it typically utilized the upper foliage of trees that had a median height 1.6 times that of $A$. drepanolobium stems throughout the study area, and a median density 8 times greater (Figure 3). As a result, 50\% of birds were encountered in vegetation of a density and height attained in less than $6 \%$ of the study area (Figure 4). Such findings do not appear to reflect an observer bias towards locating and following conspicuous (high-feeding) individuals, since the number of observations made in each sequence was unrelated to the foraging height of the bird(s) observed. Moreover, most birds were detected first by sound, and very few were encountered foraging in sparse stands, where they might also be expected to be more conspicuous.

While Karamoja Apalis appears to be restricted to Uganda, Tanzania and Kenya, the range of A. drepanolobium spans seven countries in East and Central Africa (Coe and 
Beentje 1991). An investigation of the warbler's affinity with A. drepanolobium, and of its dispersal capabilities, might help explain disparities in their respective distributions. It might also help explain the species' unusually long bill, which may be adapted to exploiting particular prey types or structures associated with A. drepanolobium, including, for example, its pseudo-galls or clusters of long spines.

Potential prey includes scale insects and, possibly, four symbiotic ant species (Crematogaster spp. and Tetraponera penzigi). The latter are common residents on $A$. drepanolobium, occurring, for example, on $99 \%$ of stems (over $0.5 \mathrm{~m}$ tall) at one site in Kenya (Stanton et al. 1999). Three of the four ant species raise their larvae in pseudo-galls (Palmer et al. 2000), and two species also tend scale insects, in one case housing these inside pseudo-galls (Palmer et al. 2000). Although no Karamoja Apalis were seen taking adult ants, individuals occasionally probed inside pseudo-galls for up to 30-40 seconds, despite attacks from ants (Shaw et al. 2004).

\section{Habitat condition}

Over the past century, woody vegetation cover in northern Tanzania has fluctuated markedly, and often rapidly, as a result of changes in the pattern and intensity of burning, grazing and browsing (e.g. Sinclair 1979, Dublin 1995, Meertens et al. 1995). In Sukumaland, a combination of factors, including cultivation, burning and tsetse control, has resulted in a largely denuded landscape (Meertens et al. 1995), in which scrub regeneration may be inhibited, in part, through a traditional system in which all grass near to homesteads is grazed down to a short sward, inimical to ticks. This also destroys inedible sward and, with goats, effectively prevents bush regeneration (Meertens et al. 1995).

Such pressures are likely to intensify as human and livestock populations increase. In the four Districts encompassing the Wembere Steppe, the human population rose by between 52\% (Iramba District) and 88\% (Singida Rural) during 1967-2002; equivalent to an increase of $2.2-3.7 \%$ per year, respectively (from National Bureau of Statistics 1982, 1991, 2003). In Igunga District, which held the bulk of the Karamoja Apalis population in the steppe, the mean rate of increase was relatively low during 1978-1988 (0.7\% per year), but increased by a factor of 6 during 1988-2002 (to $4.3 \%$ per year). Since a high proportion of the human population is directly involved in agriculture, this rapid increase is likely to have had an adverse impact on the volume and condition of woody vegetation in the steppe. Indeed, clearing, pruning and browsing of $A$. drepanolobium were widespread within the areas examined.

Habitat loss and fragmentation appear to be the principal threats to the Karamoja Apalis population in the Wembere Steppe, there being no evidence of other pressures, such as persecution or collecting. Our findings are drawn from a brief study in one area, however, and may not be representative of the species' habitat requirements in other seasons or at other sites. Further research is required to measure change in the species' habitat and population, to clarify its status in protected areas within the Serengeti ecosystem, and to determine the nature of its dependence on $A$. drepanolobium.

\section{Acknowledgements}

This study would not have been possible without financial support received from the Rufford Foundation and the British Ornithologists' Union, for which we offer grateful 
thanks. We also thank the Tanzania Commission for Science and Technology for granting permission for the study to proceed (Permit 2003-107-NA-2002-67), BirdLife International for allowing access to correspondence on the species' status, and Neil and Liz Baker for their advice and generous hospitality. We are also grateful to Njano and Maneno Mbilinyi for their valuable assistance with fieldwork, to Paul Buckley, Françoise Dowsett-Lemaire, David Moyer, Des Thompson, Hugo Rainey and an anonymous reviewer for their advice, to Richard Ranft and Nadine Svoboda for their assistance with sound recording equipment, and to Joseph Mackubi, Martin and Juma Augustine Ngoy for their companionship in the field.

\section{References}

Baker, N. E. and Baker, L. M. (2002) Important Bird Areas in Tanzania: A First Inventory. Dar es Salaam: Wildlife Conservation Society of Tanzania.

BirdLife International (2000) Threatened Birds of the World. Barcelona and Cambridge, U.K.: Lynx Edicions and BirdLife International.

Buckland, S. T., Anderson, D. R., Burnham, K. P. and Laake, J. L. (1993) Distance Sampling: Estimating Abundance of Biological Populations. London: Chapman and Hall.

Coe, M. and Beentje, H. (1991) A Field Guide to the Acacias of Kenya. Oxford: Oxford University Press.

Collar, N. J. and Stuart, S. N. (1985) Threatened Birds of Africa and Related Islands. The ICBP/IUCN Red Data Book, Part 1. Cambridge, U.K.: International Council for Bird Preservation \& International Union for Conservation of Nature and Natural Resources.

Dowsett-Lemaire, F. (1989) Ecological and biogeographical aspects of forest bird communities in Malawi. Scopus 13: 1-80.

Dublin, H. T. (1995) Vegetation dynamics in the Serengeti-Mara ecosystem: the role of elephants, fire and other factors. Pp. 71-90 in A. R. E. Sinclair and P. Arcese, eds. Serengeti II. Dynamics, Management and Conservation of an Ecosystem. London: The University of Chicago Press.

Fry, C. H., Keith, S. and Urban, E. K., eds. (2000) The Birds of Africa. Vol. VI. London: Academic Press.

Meertens, H. C. C., Ndege, L. J. and Enserink, H. J. (1995) Dynamics in Farming Systems: Changes in Time and Space in Sukumaland, Tanzania. Amsterdam, The Netherlands: Royal Tropical Institute.

Monadjem, A. (2002) Population densities and community structure of birds in Acacia savanna in the lowveld of Swaziland. Ostrich 73(1\&2): $11-19$.

National Bureau of Statistics (1982) 1978 Population Census Preliminary Report. Dar es Salaam, Tanzania: Bureau of Statistics, Ministry of Finance and Planning.

National Bureau of Statistics (1991) Tanzania Sensia 1988. Dar es Salaam, Tanzania: Bureau of Statistics, President's Office, Planning Commission.

National Bureau of Statistics (2003) Tanzania Sensia 2002. http://www.tanzania.go.tz/census

Palmer, T. M., Young, T. P., Stanton, M. L. and Wenk, E. (2000) Short-term dynamics of an acacia ant community in Laikipia, Kenya. Oecologia 123: 425-435.

Rainey, H. J. (1996) Search for the Karamoja Apalis Apalis karamojae near Mt Kadam, Moroto District, Uganda. Unpublished report.

Remsen, J. V. and Robinson, S. K. (1990) A classification scheme for foraging behaviour of birds in terrestrial habitats. Studies Avian Biol. 13: 144-160.

Shaw, P. and Shewry, M. (2001) Population density and habitat associations of restricted-range bird species at Ruhija, Bwindi Impenetrable Forest, Uganda. Bird Conserv. Int. 11: 161-174.

Shaw, P., Mungaya, E., Mbilinyi, N. and Mbilinyi, M. (2004) The Status and Habitat of Karamoja Apalis Apalis karamojae in the Wembere Steppe, Sukumaland, Tanzania, 2003. Unpublished report. Dar es Salaam: Wildlife Conservation Society of Tanzania. 
Shaw, P., Mungaya, E., Mbilinyi, N. and Mbilinyi, M. (2005) The voice and bill length of Karamoja Apalis Apalis karamojae are atypical of the genus. Bull. Brit. Ornithol. Club 125: 122-129.

Sinclair, A. R. E. (1979) Dynamics of the Serengeti ecosystem: process and pattern. Pp. 1-30 in A. R. E. Sinclair and M. Norton-Griffiths, eds. Serengeti: Dynamics of an Ecosystem. London: The University of Chicago Press.

Stanton, M. L., Palmer, T. M., Young, T. P., Evans, A. and Turner, M. L. (1999) Sterilization and canopy modification of a swollen thorn acacia tree by a plant-ant. Nature 401: 578-581.

Stattersfield, A. J., Crosby, M. J., Long, A. J. and Wege, D. C. (1998) Endemic Bird Areas of the World: Priorities for Biodiversity Conservation. Cambridge, U.K.: BirdLife International.

Steinberg, D. and Colla, P. (1997) Logistic regression. Pp. 67-129 in Anon. SYSTAT 7.0: New Statistics. Chicago: SPSS Inc.

Stuart, S. N. and Collar, N. J. (1985) Subspeciation in the Karamoja Apalis Apalis karamojae. Bull. Brit. Ornithol. Club 105: 86-89.

Urban, E. K., Fry, C. H. and Keith, S., eds. (1997) The Birds of Africa. Vol. V. London: Academic Press.

PHILIP SHAW

Scottish Natural Heritage, Battleby, Redgorton, Perth PHI 3EW, U.K. E-mail: phil.shaw@ snh.gov.uk

ELIAS MUNGAYA

Wildlife Conservation Society of Tanzania, P. O. Box 70919, Dar es Salaam. Tanzania. E-mail: ezm1@leicester.ac.uk

Received 12 November 2004; revision accepted 23 June 2005 